\title{
ADAPTASI MASYARAKAT DI PEMUKIMAN PASCABENCANA: (STUDI PADA INTERAKSI SOSIAL DI PERUMAHAN JACKY CHAN, DESA NEUHEN, KABUPATEN ACEH BESAR)
}

\author{
Nurkhalis \\ Dosen Prodi Ilmu Sosiologi FISIP Universitas Teuku Umar
}

\begin{abstract}
Abstrak
Kehadiran tempat tinggal baru disebabkan faktor bencana alam, dengan orang menempatinya berasal dari beragam suku dan profesi, pada dasarnya interaksi sosial rentan mengalami kesulitanmenimbulkan perselisihan, persengketaan dan bahkan berujung pada konflik. Adapun artikel ini bertujuan untuk mengetahui apa saja proses penyesuaian diri di perumahan jacky chan. Metode dalam penelitian ini kualitatif dengan pemilihan beberapa informan di dalamnya menggunakan teknik Snow Ball dan teori menggunakan teori konstruksi sosial dari Peter Berger dan Thomas Luckmann. Maka hasil penelitiannya diperoleh bahwa Interaksi; Praktik Keagamaan (Wirid, Tahlilan, Dzikir), kegiatan sosial (gotong royong, menjenguk orang sakit dan ibu melahirkan), dan toleransi sosial beragama.
\end{abstract}

Kata Kunci: Adaptasi, Interaksi, Konstruksi Sosial, Toleransi 


\section{PENDAHULUAN}

Program pemerintah yang mewujudkan pemukiman baru bagi kelompok di suatu masyarakat menjadi salah satu pilihan menyejahterakan keberlangsungan penataan hidup sehingga pada akhirya memungkinkan pemenuhan kebutuhan lain, seperti pendidikan, sosial, ekonomi, politik dan sisi religius (keagamaan). Namun, seringkali pengalaman dalam memikirkan berbagai ide pembangunan bagi masyarakat di Indonesia kurang memahami sifat-sifat yang ditimbul di kemudian hari, sehingga kembali menimbulkan persoalan yang semakin berkelinden.

Beberapa dari persoalan tersebut di antaranya, terletak pada ketergantungan pada organsisasi-organisasi birokratis terpusat yang hanya mempunyai sedikit kemampuan untuk menanggapi beraneka ragam kebutuhan khas komunitas atau untuk membangun berdasarkan keahlian dan nilai-nilai komunitas. Serta, adanya investasi yang tidak memadai dalam proses pengembangan kemampuan komunitas untuk memecahkan masalah. Dan selanjutnya, perhatian yang kurang dalam menangani keanekaragaman masyarakat, terutama dalam hal struktur sosial pedesaan yang sangat berlapislapis. ${ }^{1}$

Dari sudut pandang sosiologis-antropologis, tsunami Aceh lebih dianggap sebagai 'bencana peradaban' karena menghancurkan seluruh pranata sosial masyarakat Aceh. Mulai dari pranata keluarga dan perkawinan yang hancur, ribuan anak harus menjadi yatim/ yatim piatu, perempuan menjadi janda, dan lelaki menjadi duda. Pranata pemerintahan dan politik juga mengalami kehancuran lembaga-lembaga modern. Pada pranata ekonomi dan perdagangan, menyebabkan kehancuran seluruh sarana dan prasarana ekonomi dan perdagangan di Aceh. Selain itu, pranata pendidikan juga mengalami kehancuran, dari banyak sekolah formal dan non formal hancur, ribuan murid dan guru tewas. Serta pranata agama, seperti mesjid yang hancur dan teungku, juru dakwah dan lainnya yang meninggal dunia. ${ }^{2}$

Tatkala pemukiman baru telah memberikan kemudahan masyarakat dalam berkehidupan. Tetapi pemukiman dengan beragam suku dan profesi menempati pemukiman pasca bencana itu nantinya tidak mudah membentuk situasi dan suasana sosial assosiatif dikarenakan perbedaan seringkali menjadi ruang adanya perselisihan hingga berujung konflik. Sebagaimana diketahui penghuni perumahan Jacky Chan merupakan para korban tsunami terdiri atas beragam latar belakang profesi, di antaranya, nelayan, penarik becak motor (ojek), pedagang, pegawai, maupun wiraswasta, dan berbagai pekerjaan

1 Tulisan David C. Korten berjudul, Penyusunan Program Pembangunan Pedesaan: Pendekatan Proses Belajar. Dalam buku David C. Korten \& Sjahrir (ed), Pembangunan Berdimensi Kerakyatan, (Jakarta: Yayasan Obor Indonesia, 1988), hal. 235

2 Alo Liliweri, Strategi Komunikasi Masyarakat (Yogyakarta: LKiS, 2010), hal 193-194 
lainnya. ${ }^{3}$ Sementara itu beragam suku dari mulai Aceh, Mandailing, Ambon, Jawa dan etnis Cina menetap di sana. Berangkat dari kondisi tersebut maka penelitian ini bertujuan mengetahui bagaimana proses adaptasi masyarakat di sana.

\section{METODOLOGI PENELITIAN}

Penelitian ini menggunakan pendekatan kualiatif secara deskriptif4. Secara sederhana yang dimaksudkan dengan deskriptif di sini, peneliti terjun ke lapangan tanpa dibebani atau diarahkan oleh teori. Peneliti dengan bebas mengamati objeknya ${ }^{5}$, menjelajah, dan menemukan wawasan-wawasan baru sepanjang jalan. ${ }^{6}$ Atau dengan kata lain, data dari penelitian kualitatif itu nantinya, data yang berasal dari kondisi obyek yang alamiah-dimana peneliti adalah instrumen kunci, teknik pengumpulan data dilakukan secara triangulasi. Analisa data bersifat induktif, dan hasil penelitian kualitatif lebih mendalam makna daripada generalisasi. ${ }^{7}$

Pada penentuan informan lebih tepatnya akan peneliti lakukan dengan menggunakan teknik Snowball. Adapun yang dimaksudkan dengan teknik Snowball, penentuan informan yang dimulai dalam kelompok kecil yang diminta untuk menunjuk kawan masing-masing. Kemudian dari kawan yang telah ada untuk kembali menunjuk kawan masing-masing pula, dan begitu seterusnya sehingga kelompok itu senantiasa bertambah besarnya, bagaikan bola salju yang kian bertambah besar bila meluncur dari puncak bukit ke bawah. ${ }^{8}$

Teknik pengumpulan data secara wawancara atau interviu adalah suatu bentuk komunikasi verbal, semacam percakapan yang bertujuan memperoleh informasi. Dalam wawancara yang dilakukan, berisi pertanyaan dan jawaban yang dalam nuansa verbal. Biasanya komunikasi dilakukan dalam keadaan saling berhadapan, namun komunikasi dapat juga dilaksanakan melalui telepon.

\footnotetext{
3 AcehTourismAgencyOnline, Kampung Jacky Chan di Aceh, diposting pada tanggal 19/11/2012, pada pukul 18:09, pada situs, http:/ / acehtourismagency.blogspot.com/2012/08/kampung-jacky-chan

4 Pemahaman deskiptif yang dimaksudkan nantinya,penelitian terus menerus mengalami reformulasi dan redireksi ketika informasi-informasi baru ditemukan. Hipotesis tidak datang sebelum penelitian tetapi hipotesis akan muncul dalam penelitian, periksa Nina W. Syam, Sosiologi Komunikasi, (Bandung: Humaniora, 2009), hal. 232

${ }^{5}$ E Kristi Poerwandari, Pendekatan Kualitatif dalam penelitian Psikologi, (Jakarta: LPSP3, 1994), hal. 9

${ }^{6}$ Jalaluddin Rakhmat, Metode Penelitian Komunikasi, (Bandung, Remaja Rosdakarya, 1985), hal. 36

7 Sugiyono, Memahami Penelitian Kualitatif, (Bandung: Alfabeta, 2007), hal. 1

8 S. Nasution, Metode Research: Penelitian Ilmiah, (Jakarta: Bumi Aksara, 2006), hal. 99
} 


\section{Adaptasi diri di Kalangan Warga Perumahan Jacky Chan}

Mengenai proses penyesuaian diri (adaptasi), ini menjadi peristiwa pertama secara dialektis berkenanaan dengan individu membentuk dunia sosialnya di dalam suatu masyarakat-mengacu pada teori konstruksi sosial. Dari apa yang peneliti dapatkan di perumahan Jacky Chan bahwa, adapun meliputi proses penyesuaian diri yang berlangsung di lingkungan perumahan terbagi kedalam dua jenis pengadaptasian, pertama, pelibatan individu dalam masyrakat yang berhubungan dengan konteks keagamaan (religius) dan kedua, keterlibatan individu yang berkaitan erat dengan konteks berbeda, yakni perihal hubungan secara sosial.

Keseluruhan Informan, dalam proses adaptasi sebagaianinforman ada yang termasuk dalam adaptasi yang pertama dan juga tergolong pada kedua. Bahkan ada satu dua informan dalam pelibatannya termasuk dalam dua adaptasi terbentuk.

\section{Praktik Bermasyarakat dalam konteksReligius (keagamaan)}

Peneliti mendapati melalui informan, proses adaptasi yang berlangsung di lingkungan perumahan Jacky Chan terjadi dalam dua prosesnya poin, penyesuaian diri di kalangan warga perumahan tersebut terkait dengan konteks keagamaan. Dimana bentuk proses penyesuaian diri itu antara lain, tergabungnya individu dalam praktikWiridan, Tahlilan dan hal lainnya, menghormati dalam perbedaan agama, dimana non muslim menghormati dan menghargai kepada kaum Muslim saat memasuki bulan Ramadhan yang diwajibkan berpuasa bagi yang beragama Islam. Dan kedua, adaptasi diri di kalangan warga perumahan Jacky Chan dalam praktik bernuansa sosial.

Dari keseluruhan informan, sebagian menyebutkan bahwa hampir disetiap acara wiridan yang rutin dilakukan saban menjelang malam Jumat (bagi kaum bapak) dan jelang siang di hari Jumat dan hari Sabtu (bagi kaum Ibu) para informan turut terlibat di dalamnya, bagi mereka dengan mengikuti dapat mewujudkan kerukunan dalam lingkungan mereka.

Hari pertama keberadaan peneliti di lingkungan perumahan Jacky Chan ketika itu, telah langsung mendapati ratusan orang memadati kawasan Blok G. Keramaian orang di sana yang dominan adalah warga perumahan Jacky Chan sendiri yang sedang menghadiri serangkaian acara prosesi mengurus Jenazah Pak Mardi, seorang Muallaf yang menempati rumah di Blok G bersama isteri dan anaknya.

Peneliti dengan berkendara dan seketika berhenti di sebuah warung yang ramai diparkirkan puluhan sepeda motor dan terdapat pula beberapa mobil di sana. Tampak sebuah kertas pertanda berwarna merah menandakan ada yang meninggal. Setelah sempat bertanya pada salah seorang pengunjung, peneliti mendapati bahwa seorang penghuni bernama Mardi (nama panggilan, Balok-sebagai seorang yang 
keturunan Cina yang kini menjadi Muallaf) telah meninggal dunia pada malam hari tanggal (28 Januari 2013). Tidak berselang lama, seratusan pengunjung yang mengerumuni halaman rumah duka sampai berpendar ke jalanan seketika bergegas dan akhirnya jalan beriringan menuruni Blok G menuju mesjid yang berada di Blok A untuk menshalatkan jenazah di sana. Peneliti ikut bersama rombongan dan melaksanakan shalat, namun tidak bersama menguburi jenazah karena letaknya susah dilalui untuk berkendara - harus berjalan kaki ke tempat pengkuburan. (Observasi, 29 Januari pukul 10:49)

Dikarenakan suasana awal ketika peneliti berada di perumahan Jacky Chan masih berkabung dalam duka atas meninggalnya Alm. Pak Mahdi. Peneliti akhirnya mengesampingkan keinginan menemui calon informan (proses peneliti memperkenalkan diri dan meminta kesedian beberapa orang untuk menjadi informan) dan berinisiatif melibatkan diri dalam praktik malam Tahlilan ke-3, yang merupakan prosesi dzikir bersama dan mendoakan Almarhum pak Mahdi.

'selepas shalat magrib berjamaah di Mesjid dengan beberapa penghuni di perumahan Jacky Chan (PJC). Peneliti menuju ke rumah Informan Kunci, Pak Ramkur untuk sama-sama mengajak Tahlilan ke rumah Alm. Mardi yang memasuki malam ke-3. Sesaat tiba di rumah duka mencoba berkenalan lebih jauh dengan orang-orang yang telah dahulu tiba, termasuk ketika itu perkenalan langsung peneliti kepada Sekretaris PJC, Husni. Tidak berselang beberapa menit, suara imam Wiridan telah terdengar untuk memulai acara tahlilan pada malam itu. Di sela-sela mengikuti tahlilan peneliti mengamati sekitaran pegunjung malam itu, mendapati berbagai kalangan yang hadir ketika itu,mulai dari orang Pribumi, suku Jawa dan beberapa suku Aceh dari berbagai wilayah Timur dan Barat kawasana Aceh, yang hal itu sempat peneliti ketahui setelah mempertanyakan kepada informan kunci selepas acara. Tahlilan berakhir pada pukul 20:30' (Observasi, 31 Januari 2013 Pukul 18: 39 s/d 20:30)

Keheningan malam sungguh terasa di kawasan blok $G$ yang bisa dikatakan bagian puncak teratas di perumahan tersebut. Setelah selesai dari acara tahlilan, selanjutnya peneliti memenuhi ajakan dari pak Ramond untuk menghadiri praktik Wiridan yang akan dilangsungkan di rumah pak Husni,malam itu juga.

'...acara wiridan yang dilakukan secara bergiliran dan untukmalamitu ditempatkan di rumah bapak Husni, yang berada di Blok E. Wiridan menjadi agenda yang dirutinkan yang tercetus pada penghujung tahun 2012. Kegiatan ini dihadirkan mengingat bahwa darinya akan timbul kekompakan bersama dari kalangan bapak-bapak penghuni di PJC. 
Setelah Wirid (membaca surat Yasinan bersama dan diakhiri doa yang dipanjatkan demi mengharapkan keselamatan bersama. Tidak hanya itupara tamu Wirid mendapat suguhan satu piring nasi dan beberapa lauk yang diberikan oleh tuan rumah yang kena giliran wirid malam itu. Peneliti yang sempat berbincang dengan salah seorang peserta Wirid yang dia juga mempunyai ikatan keluarga dengan bapak $\mathrm{Ni}$ menuturkan, "Saya berasal dari Ponorogo. Selama saya tinggal di sini ya jika ada Wiridan ya saya akan menyempatkan diri hadir walaupun sehari lelah bekerja sebagai tukang bangunan... ya hitung-hitung bisa saling mengenal banyak orang agar semakin bisa akrab, ' ujarnya, yang tidak sempat peneliti bertanya nama. Setelah menyantap makanan dan menyeruput teh hangat, jam sudah menunjukkan pukul 23:00, suasana di PJC di guyur hujan namun tidak mengurungkan niat para yang hadir untuk bergegas pulang karena hari semakin larut.' (Observasi, 31 Januari 2013 Pukul 20: 45 s/d 23:00)

Seperti apa yang dituturkan oleh Ibu Lusy, bahwa acara Wiridan dan Tahlilan menjadi bagian yang dijalaninya secara alami. Dalam berbagai kesempatan Wiridan yang dilangsungkan pada jelang siang di hari Jum'at membuat para ibu-ibu bukan saja untuk blok F namun blok lainnya (blok $G$ ) turut ikut serta sehingga akhirnya bisa menjalin toleransi antarsesama mayoritas Islam

“... saya namanya ibu rumah tangga, ya kalau ada pengajian dan wiridan dan ada orang yang meninggal ya ayok kita berkunjung. saya ga tahu bilang ya gimana yang berkesan, secara natural ya saya jalaninya ya harus menjiwai untuk tinggal di sini.." Kita jadi jumpa wiridan ya itu saja yang buat kita berkumpul dengan blok-blok yang berbeda." Kalau di sini ya baik toleransi dalam beragama ya baik-baik saja karena kita mayoritas Islam..." (Wawancara dengan informan ibu Lusy, 54 Tahun, rumah blok F-38, 06 Februari 2013 (pukul 14:00 s/d 14:39)

Sempat di suatu kesempatan peneliti ikut melibatkan diri dalam acara Wiridan Ibu-ibu yang berlangsung di rumah ibu Ika yang juga berada di blok F. Dan terlihat di acara tersebut informan ibu Lusiana berada di sana:

'Peneliti datang terlebih dahulu (20 menit sebelum acara Wiridan dimulai) untuk meminta izin kepada ibu yang kena giliran melangsungkan Wiridan, yakni Ibu Ika. Setelah peneliti memperkenalkan diri dan memberikan penjelasan maksud kedatangan peneliti yang berujung pada perizinan untuk terlibat malahan dengan sopan dan ramahnya Ibu Ika menyarankan untuk masuk saja di dalam rumah. Dalam pengamatan peneliti, sejak pukul 14: 45 ibu-ibu sudah mulai berdatangan turut membawa anaknya serta. Dalam sela-sela menunggu, ada yang menyelesaikan keuangan rutin yang dibiayakan 
bagi masing-masing ibu yaitu Rp 5.000/ minggu. Dana terkumpul untuk kemudian diserahkan kepada tuan rumah (yang kena giliran) pada minggu berikutya, sekedar mempersiapkan hidangan minuman dan makanan bagi mereka yang telah berdoa. Sebelum dimulainya wiridan, seorang ibu pemimpin berceramah (yang telah ditunjuk karena memiliki pemahaman agama yang lebih daripada yang lain) diawali dengan perihal membaca doa apa-apa saja ketika hendak memulai membaca surat Yasin, kemudian beberapa anjuran meniatkan kepada siapa bacaan Yasin kita akan ditujukan agar mendapat berkah yang akan lebih afdhol bila diucapkan dengan bahasa Arab. Dan tidak sedikit pula ada yang bertanya di luar pembahasan namun masih tetap dalam koridor kajian Fiqih. "Kita sebagai seorang Ibu sepatutnya menjadi istri yang salehah dan juga bisa berakhlak mulia sehingga akhirnya nanti bisa dicontohkan kepada anak kita nantinya." Jelas sang penceramah yang didengarkan oleh puluhan ibuibu yang turut serta.' (Observasi, 16 Februari 2013 pukul 14:39).

Lebih lanjut ibu Lusy menuturkan tentang alasan dirinya beradaptasi dengan mengikuti acara Wiridan, bahwa menurutnya dengan cara seperti itu memiliki sikap terbuka (ekstovert) dan bersahabat dengan warga lainnya. Yang jelas bagi informan Lusiana proses adaptasi menjadi kebutuhan yang bisa saja suatu ketika kapan itu pastinya manusia membutuhkan orang lain membantunya (mahluk sosial),

“Ya saya mau gimana saya dengan mereka dan mereka dengan saya, ada keinginan melebur untuk berinteraksi dengan mereka. Misalnya seperti dulu, pas saya datang acara wirid, ada yang bertanya, "Kemana saja ga pernah nampak," ya saya bilang, "bapak sakit" ya kemudian mereka jenguk bapak yang sakit. Ya kalau kita di rumah menutup diri ya orang ga kenal kita. Orang ga kenal kita suatu saat kita butuh orang karena kita ada musibah, sakit dan ada kenduri maka ntah apa orang ga tahu. ..." (Wawancara dengan ibu Lusy 54 Tahun, rumah blok F-38, 06 Februari 2013 (pukul 14:00 s/d 14:39).

Di Minggu-minggu berikutnya, kembali peneliti melibatkan diri dalam acara wiridan yang ada di blok F. Terlihat ketiga informan, ibu Lusy, Ibu Sisy dan Ibu Del turut hadir dalam wiridan tersebut.

'Hari itu, berlangsung acara wiridan khusus bagi penghuni di Blok F berlokasi di rumah F-46. Sebelumnya peneliti telah datang lebih awal untuk meminta izin sebelum acara dilangsungkan. Dalam pengamatan sembari menunggu mereka yang datang, peneliti memperhatikan dengan seksama yang disana ada informan ibu Lusiana sedang berbicara dengan yang lainnya. "Maaf ibu... Sabtu lalu saya ga bisa datang dikarenakan bapak lagi kurang enak badannya. Jadi saya ga mungkin pergi meninggalkan bapak. Hari saya datang karena badan sudah 
tampak fit..." Jawab ibu Lusy yang dituju kepada orang yang bertanya ketidakhadirannya sabtu lalu. Setelah dirasakan rumah telah diisi oleh ibu-ibu yang datang (tampak di sana informan ibu Siti Deliana datang juga). Terlebih dahulu seorang ibu mempimpin acara wiridan dengan dimulai mengucapkan salam, puji-pujian kepada Allah dan shalawat kepada rasul dan setelah dibuka sesi untuk bertanya kepada perihal tentang keagamaan. Acara wiridan tidak sekedar membaca yasin bersama juga diselingi dengan perbincangan Tanya jawab agama dan pengajaran seputar lafadz dan maknanya ketika hendak memulai membaca yasin. "Ibu selalu harapkan untuk datang, sambil ngendong anak walaupun ia tidur dipangkuan ibu hadir di sana. Ya... gimana ya adek, soalnya sebagai muallaf ibu juga pengen bisa pintar mengaji dan tahu permasalahan agama." Ujar ibu Sisy yang peneliti temui setelah wiridan selesai. (Observasi, 23 Februari 2013 pukul 14:40).

Seperti halnya informan ibu Sisy yang merupakan Muallaf. Telah menambah daftar atas mereka yang meneguhkan diri untuk masuk agama Islam. Dari data yang disebutkan pak Husni, bahwa ada sekitar 30\% warga etnis Tionghua berada di perumahan tersebut, baik awalnya berasal dari agama Buddha dan Kristen telah mengikrarkan syahadat untuk masuk agama baru mereka, yaitu Islam. Adapun upaya yang dilakukan melalui perangkat (strukur) kepemerintahan di lingkungan Jacky Chan dengan mengadakan pengajian bagi para Muallaf tersebut, agar pendalaman agama mereka bisa didapatkan di tempat tersebut. Lebih jelas simak penuturan pak $\mathrm{Ni}$,

“... mereka (para Muallaf) dulu kebanyakan masuk islam belum jelas, jadi di saat di sini ya akhirnya sudah diperdalam dan diperjelas karena sudah berbaur dengan orang islam yang ada di sini. Dahulu pernah ada program pengajian untuk para muallaf di tahun 2012 namun sempat terhenti kini." (Wawancara dengan pak Ni, Sekretaris Perumahan Jacky Chan, 28 Februari 2013 pukul 00:00 s/d 01:54)

Selanjutnya, acara Wiridan bukan saja menjadi kegiatan yang dilangsungkan oleh para ibu-ibu namun juga menjadi kegiatan pilihan kaum bapak-bapak. Informan lain, pak Armansyah juga mengakui hal serupa bahwa untuk membuatnya beradaptasi dengan lingkungan di tempat tinggalnya, maka ia mendorong diri untuk terlibat dalam setiap acara Wiridan yang juga dilangsungkan pada malam hari Jumat (Kamis malam).

"Ya setidaknya kita tahu ke tempat orang Aceh, ya kita baik-baik dulu kemudian kita pelajari. Saya sangat setuju sekali dari adanya Wirid tiap malam Jumat. Lebih banyak lebih bagus. Awalnya saya ketika saya tinggal di sini, berhubung wiridan baru-baru saja terbentuk saat saya ke rumah pak Ni (Sekretaris komplek) kemudian saya meminta gabung. Ya dorongan dari diri sendiri. Yang jelas kita mengenal orang-orang di Blok 
lain..." (Wawancara dengan bang Nyong, 48 Tahun, rumah Blok G-11, 14 Februari 2013 (pukul 10:40 s/d 11:43).

Mengenai berbagai kegiatan yang dilangsungkan di perumahan Jacky Chan, seperti acara Wiridan, membawa kepada bertemunya komunitas beragama Islam di dalamnya, awal mula terencananya praktikWirid tersebut, menurut penuturan dari apa yang telah dilacak dari bapak Ni. Praktik Wirid Jumat malam khusus bagi kaum bapak-bapak berawalinisiatif blok A dan kemudian berangsur-angsur menjadi persetujuan bersama sehingga pada akhirnya diikuti oleh orang di seluruh blok lainnya.

“... itu kan kayak wirid orang bapak-bapak itu, ya dimulai dari blok A mereka punya inisiatif, dengan saling bertanya, "bagaimana kalau dari malam-malam lain kita duduk kenapa tidak malam jumat kita buat wirid yasin." Walau yang mulai orang blok A, mereka yang ikut ya siapa saja boleh... Dimulai wird ya... tahun 2012. Kalau ibu ya setiap blok ada wirid setiap kelompok ada masing-masing, ya itu ada perbedaan bukan perbedaan apa ya.. ya maksudnya gaya dalam membangun komunikasi aja yang berbeda, gaya dalam membuat acara misalnya di blok F bikin wirid hari jumat abes jumat dan di blok E bikin wirid hari jumat jam empat itu aja yang beda-beda. Tapi konsep yang mereka bangun ya sama semua. Artinya apa mereka menciptakan eeee... perkumpulan terjadi silaturrahim antara sesama ibu-ibu blok, ya tapi kalau dibuat keseluruhan di mesjid ya tidak terjangkau, akhirnya ya ibu ada anakanak ya dibuat masing-masing blok."(Wawancara dengan Husni, Sekretaris Perumahan Jacky Chan, 28 Februari 2013 pukul 00:00 s/d 01:54)

Di suatu malam, tepatnya selepas shalat magrib, peneliti sempat berbincang dengan salah seorang Jamaah shalat Magrib, bernama pak Jufri yang berprofesi sebagai guru agama di sekolah yang berkawasan di Aceh Besar. Beliau telah ditunjuk oleh kalangan warg menjabat sebagai Bendahara untuk mengelola iuran bulanan warga yang bergabung dalam acara Wiridan bapak-bapak.

'Pada saat itu, bapak Juf mengeluarkan buku yang akhirnya jelas peneliti melihatnya, bahwa itu adalah buku Iuran (karena pada saat itu ada seseorang dari warga membayar uang iuran wiridnya. Peneliti merasa karena telah menetap sementara waktu dengan menemati blok E-42, menawarkan diri untuk diperkenankan menjadi anggota sehingga dapat mengisi beberapa Wiridan bapak-bapak yang peneliti itu, namun pak Jufri terkesan menolaknya, "Sudah... tidak perlu membayar, lagian adek kan tidak lama tinggal di sini, sekedar ingin meneliti saja kan...?" Ungkap pak Jufri yang bertanya pula mengenai status peneliti di sana. Peneliti sempat berbincang lebih jauh, menurutnya, "Ya ini baru saja digagas acara 
Wiridan, dan akhirnya kami sepakat adanya iuran untuk meringankan tuan rumah menyediakan makanan dan minuman bagi warga yang datang Wiridan. Biasanya yang kena giliran mengadakan Wiridan ya akan ditetapkan atau ada yang meminta kesediaan diri diadakan di rumahnya..." jelas pak Jufri lebih lanjut. (Observasi, 21 Februari 2013)

Lingkungan perumahan Jacky Chan yang tampak dari amatan peneliti, sarat dengan berbagai perkumpulan berkonteks-kan keagamaan (khususnya komunitas Islam). Apabila pada wawancara dan pengamatan peneliti sebelumnya, menemukan bahwa praktik Wirid menjadi bagian aktivitas bapak dan ibu-ibu rutin mingguan. Maka dzikir bersama turut menjadi aktivitas yang dilakukan oleh anak-anak TPA saban Juamt sore di Mesjid perumahan tersebut.

'... peneliti shalat Ashar berjamaah di mesjid perumahan Jacky Chan. Tidak banyak jamaah bapak dan ibu di mesjid tersebut. Hanya beberapa anak-anak dan remaja berkumpul di sana dan shalat pun diimami Tgk. Iskandar yang tidak lain adalah Bilal sekaligus guru mengaji di TPA perumahan Jacky Chan. "Di sini yang mengaji hanya tiga puluh orang saja, dan pengajar ada empat, saya dan dibantu tiga gadis dan gadis itu juga seusai mengajar anak-anak, saya lanjutkan mengajar mereka mengaji." Ujar Tgk Is, yang rumahnya hanya selemparan pandangan dari arah utara Mesjid. "Ohh ya... sore ini gabung saja, saya ajak anakanak untuk hari Jumat tidak mengaji tapi digantikan dengan belajar dzikir dan tahlilan, yang diperbantukan dengan buku pedoman dan dibimbing ibu anak-anak yang kadang datang secara bergantian," Ungkap Tgk. Is sambil mengajak peneliti bergabung kala itu. (Observasi, 08 Januari 2013 pukul 16: 29).

Selain itu, adanya Wirid, Tahlilan, Dzikir serta juga dihiasi dengan kebersamaan antara kalangan warga perumahan Jacky Chan dengan pelaksanaan Seunujoh. ${ }^{9}$ Berhubung Almarhum bapak Mardi baru saja meninggal ketika itu, maka memasuki malam ke-7 warga berdatangan untuk kembali membaca Yasin dan doa bersama, serangkaian acara tidak berbeda atau serupa seperti dalam pelaksanaan Wiridan.

'...peneliti tiba ke acara Seunujoh bersama dengan pak Ramkur. Acara dimulai dengan membaca Yasin bersama, mengakhiri dengan doa yang dipanjatkan demi keselamatan bagi Almarhum dan selanjutnya dari yang punya rumah menyediakan makanan dan minuman sebagai tanda

${ }^{9}$ Seunujoh, merupakan kata yang disebutkan dalam bahasa Aceh, yang berarti ialah hari ke-7. Dimaksudkan bahwa ketika ada yang meninggal dunia, maka Seunujoh telah sangat lazim dilaksanakan di seluruh Aceh dengan kembali membaca Yasin dan doa kepada Jenazah yang dipimpin Imam yang didatangkan ketika malam Seunujoh. Dan bahkan mungkn juga di seluruh daerah yang masuk lingkup Indonesia bagi mereka beragama Islam saat ada yang meninggal dunia, maka acara ini akan turut pula dilangsungkan. 
terima kasih saling mendoakan (ini yang sangat dikhususkan, apabila pada malam Tahlilan tuan rumah sekedar memberikan minuman the atau kopi dan beberapa kue yang sudah ditaruh dalam Ceupe (baca Indonesia: piring kecil). Pada saat makan bersama berlangsung, peneliti terus mengamati khususnya informan-informan peneliti. Dalam pengamatan peneliti dan mendengar beberapa perihal yang diperbincangkan mulai dari menanyakan kabar dan saling mengingatkan pada satu dua hal perencanaan di perumahan Jacky Chan. "Suasana keakraban kerap muncul sewaktu kami bisa bersama-sama hadir di acara arisan yang awalnya dimulai dengan membaca Yasin beserta doa." Imbuh pak Ni, Sekretaris Kompleks di Perumahan Jacky Chan. (Observasi dan Wawancara, 14 Februari 2013 pukul 20:10).

Telah hidup bersama dalam satu lingkungan perumahan, menyebabkan kalangan warga ketika membahas tentang keadaan yang apabila ada seorang warganya yang kemalangan (meninggal), selain senantiasa akan mengurusi berbagai prosesi sampai Jenazah dikuburkan dan hal lainnya menjadi pertimbangan kemudian adanya sumbangan yang dibebankan dengan sebelumnya bersepakat bersama untuk diberikan kepada keluarga Almarhum, disebut dengan fardhu Kifayah. ${ }^{10}$

"Ada fardhu kifayah itu sudah berjalan telah 2 tahun di kompleks ini, ya kita harus buat kesepakatan yang optimal ya sehingga di waktu ada yang kemalangan musibah kita tidak tergesa-gesa untuk menenggapi hal yang demikian sehingga sudah tercover dan kita cepat siap dan sudah jadi prosedur kita." (Wawancara dengan Tgk. Di, ketua kompleks Perumahan Jacky Chan, 22 Februari 2013 pukul 17:00 s/d 17:40)

Selanjutnya, pak Nisempatberbicara penyesuaian diri kalangan warga di sana pada kaidah ibadah yang lain, sepertipada saat berpuasa di bulan Ramadhan bagi kaum Muslim. Dimana tetap saja ketika bulan Ramadhan menurutnya apa yang terlihat dari proses kesadaran non muslim yang telah sebelumnya dihimbau menutup warung. Maka dengan proses penyesuaian diri mereka setuju danmenghormati yang berpuasa sehingga menutup warung sehingga bisa disebut perilaku tersebut yakni toleransi beragama. Selain itu,

10 Fardhu Kifayah, yakni suatu hukum yang diarahkan kepada pelaksanaan secara bersama, biasanya dalam Fardhu Kifayah ini ketika ada sekelompok orang saja bisa melakukannya, maka sudah barang pasti telah membebaskan yang lainnya dari kewajibannya sesame Muslim. Fardhu KIfayah yang dinyatakan di sini berbicara mengenai kewajiban Muslim terhadap Muslim lainnya ketika ada yang meninggal dunia, mulai dari mengurusi yang diawali dengan memandikan, mengkafani, menshalatkan dan menguburkan Jenazah. Berbeda halnya dengan Fardhu Aini, adalah hukum yang diwajibkan dilaksanakan kepada pribadi manusia (Aini), ketika akan berbicara pada konteks agama Islam berarti ibadah yang menjurus kepada Fardhu Aini adalah Shalat Lima Waktu dan Berpuasa di Bulan Ramadhan. 
ketika ada yang meninggal pula maka semua (tanpa terkecuali) warga perumahan Jacky Chan masih peduli satu sama lainnya.

“Apabila puasa ya umumnya sama, dengan etnis ya ga pengaruh. Ga pernah kita lihat yang non muslim saat kita bepuasa ga da non muslim yang makan. Yang jelas toleransi di sini ya tidak pernah ternodai. Kalau dengan warung tutup ketika ada yang meninggal ya awalnya sekedar himbauan, namun lama kelamaan akhirnya mereka semua sadar untuk melakukan (menutup warung), kalau disini ya kalau ada orang yang meninggal ya semuanya masih peduli lah...." (Wawancara dengan Husni, Sekretaris Perumahan Jacky Chan, 28 Februari 2013 pukul 00:00 s/d 01:54)

Peneliti yang sempat mempertanyakan apakah adanya sebuah peraturan yang telah digagas perangkat dalam struktur kepemerintahan di lingkungan perumahan Jacky Chan mengenai tata berlangsungnya acara Wiridan dan Tahlilan di sana. Menurut pak $\mathrm{Ni}$, aturan mengenai berbagai praktik keagamaan di sana berlaku dengan aturan adat di Aceh menandakan bahwa legitimasi bersifat informal.

“... himbauan atau aturan berlaku umumnya dengan aturan di Aceh. Ada aturan adatlah, saling peduli saling menghormati."(Wawancara dengan Husni, Sekretaris Perumahan Jacky Chan, 28 Februari 2013 pukul 00:00 s/d 01:54)

Dari berbagai pernyataan yang telah diutarakan oleh beberapa informan dan juga Tgk Di dan pak Ni, mengisyaratkan bahwa, kalangan warga di sana melakukan apa yang dinamakan dengan proses penyesuaian diri dari interaksi mereka dengan serangkaiaan kegiatan bernuansa religius yang awalnya bermula dari inisiatif sekelompok orang yang kemudian berujung pada persetujuan bersama untuk sama-sama menyelenggarakannya.

Proses penyesuaian diri indivdidu pada konteks keagamaan, tampak melewati dua proses penting di sana. Pertama, proses pelembagaan/ institusi dan legitimasi. Dimana ketika terhadirkan acara wiridan yang membentuk kelembagaan di dalam kalangan penghuni blok. Misalkan saja untuk wirid ibu diadakan di blok E, F, dan G. dan kaum bapak hanya dilangsungkan bergantian dengan kepengurusan inti berada untuk di blok A.

Selanjutnya, pada tatanan legitimasi mengarah kepada apa yang disebut dengan legitimasi secara lisan terwujud dalam kepribadian (legitimasi informal).Walaupun demikian legitimasi tersebut memiliki kekuatannya karena berporos pada praktik keagamaan (Wirid) dan toleransi yang di dalamnya berlangsung eksternalisasi di kalangan warga perumahan Jacky Chan. 


\section{Praktik Masyarakat yang Bernuansa Sosial}

Apa yang terjadi dalam berbagai proses penyesuaian diri di kalangan warga perumahan Jacky Chan bernuansa sosial, yaitu interaksi dan komunikasi antara individu yang satu dengan lainnya, seperti adanya saling bantumembantu menawarkan jasa angkutan bagi para pejalan kaki (mengingat rute jalan yang ada di perumahan tersebut berbentuk bukit, bagi pejalan kaki meski mendaki dan menuruni jalanan). Kemudian adanya kegiatan gotong royong yang dijalani oleh semua warga, selain itu adanya partisipasi secara bersamasama untuk menjenguk apabila ada salah seorang warga yang sakit.

Dalam pelibatan diri terhadap praktik masyarakat bernuansa sosial, sebenarnya beberapa informan pada bagian ini masih dipengaruhi (menyinggung) atau tetap terhubung dengan beberapa adaptasi berkonteks keagamaan sebelumnya. Meskipun begitu,beberapa Informan seperti ibu Ofa (etnis Tionghua beragama Kristen) dan Kakak Des (etnis Tionghua beragama Buddha) murni mengusung adaptasi mereka bernuansa sosial di kalangan warga perumahan Jacky Chan. Berkenaan dengan adaptasi diri bernuansa sosial yang masih ikut membawa penyesuaian diri berkonteks agama, seperti apa yang dinyatakan oleh Informan Desliana,

“... kalau ada kemalangan ya rasa persatuan di sini, misalnya ketika hampir malam terakhir itu antara blok bergantian buat kue (menyediakan untuk kebutuhan Tahlilan).Ya kita kompak..." (Siti Deliana 44 Tahun, rumah blok G-06, 11 Februari 2013 ( pukul 10:30 s/d 11:04)

Sebagai warga yang menempati blok G, Informan ibu Del mengakui setiap adanya warga yang meninggal dunia, maka pelibatan kaum ibu-ibu menyediakan hidangan kue secara bergiliran untuk malam pertama sampai malam ke-3 ke rumah duka. Hal tersebut dilakukan mengingat bahwa adanya acara Tahlilan hingga malam ke-3 maupun Seunujoh yang berlangsung di malam ke-7 didatangi oleh kaum bapak-bapak untuk membaca Yasin dan mendoakan Jenazah dan seketika telah selesai maka tamu akan disuguhkan minum dan makanan berupa kue berasal dari pemberian ibu-ibu sebagai tanda terima kasih kepada para hadirin yang mengikuti Tahlilan dan Seunujoh.

Masih membicarakan Informan ibu Del, yang berasal dari Ayah Ibu, kelahiran Mandailing dan Sunda mengakui bahwa penyesuaiannya diri bernuansa sosial lebih kepada perilaku duduk bersama dan berbagi bumbu atau masakan kepada warga lainnya (sebatas pada lingkup blok tempat ia menetap).

“Ya memang harus adaptasi, ya duduk ya bicara-bicara. Dahulu pertama kali belum ada banyak orang. Jadi menyesuaikan diri ya kenal mereka saja. Setelah masak dan makan kita duduk-duduk dan sore juga duduk lagi..." (Wawancara dengan ibu Del, 44 Tahun, rumah blok G-06, 11 Februari 2013 (pukul 10:30 s/d 11:04) 
Dalam sebuah amatan peneliti terhadap informan ibu Del, Peneliti berkendara berkeliling antara blok $F$ dan $G$. ketika tiba di blok $G$, peneliti langsung melihat informan Ibu Desliana telah berada di halaman rumah tetangga bencengkrama sambil mengendong anak mereka mereka. Tetangga ibu Desliana merupaka campuran Jawa (Suami) dan Aceh (Istri), namun dalam pengamatan penulis tidak ada kesulitan dalam meladeni setiap pertanyaan dan perbicangan yang diutarakan oleh tetangganya. Alih-alih peneliti menemukan faktor yang menyebabkan tiada rasa canggung ibu Desliana untuk berinteraksi.

"ya kami kalau sudah ngumpul ya bisa memaklumi. Sewaktu sesama orang Aceh kumpul ya mereka memang bicara dalam bahasa Aceh. Namun, sewaktu saya datang langsung topik yang dibicarakan diubah dalam bahasa Indonesia. Ya gitu lah di sini, " jelas ibu Del kepada peneliti.' (Observasi, 21 Februari 2013 pukul 08:33)

Selanjutnya dalam proses adaptasi sosial oleh bang Nyong. Dimanadalam kesehariannya ketika akan berinteraksi dengan kalangan warga perumahan Jacky Chan yang dominan dihuni oleh suku Aceh. Makabang Nyong mau tidak mau untuk harus mengakrabkan diri dengan membawa gaya komunikasi yang perkenalan dan berbicara dengan menggunakan bahasa Aceh.

“... ya saya saling berkenalan dan mencoba untuk menggunakan bahasa Aceh. Ada yang bertanya, Abang asli mana, maka saya jawab saya orang Ambon sudah lama tinggal di Aceh. Kakek saya Aceh orang Idi Rayeuk. Ya sewaktu saya ingin pergi ke kota saya berjumpa dengan orang Cina, anak sekolahan maka saya akan mengajak mereka bersama ketika saya mengendarai sepeda motor. Ya kita sering berkumpul dengan orang yang berbeda-beda Blok sambil berbncang-bincang..." (Wawancara dengan bang Nyong 48 Tahun, rumah blok G-11, 14 Februari 2013 (pukul $10: 40 \mathrm{~s} / \mathrm{d} 11: 43)$

Berkenaan dengan adaptasi diri bernuansa sosial yang dilakukan oleh bang Nyong, simak amatan peneliti berikut ini.

'Jelang siang, peneliti kembali bergerak menuju blok G, tepatnya di kediaman pak Armansyah. Terlihat pak Armansyah kala itu berada di luar rumahnya sedang bercengkrama dengan tetangga di depan rumahnya. Suasana berlangsung dengan sangkat akrabnya diselingi canda tawa. Seseringkali ketika jelang sore peneliti beristirahat di warung pojok atas perumahan Jacky Chan dan saat akan pulang peneliti melewati rumah pak Armansyah mendapatinya sedang bersama istri sembari mengendong anak berbicara dengan kerumunan bapak dan ibu lainnya. Menurut penjelasan mereka di kemudian hari, biasanya 
kumpulnya mereka akan bubar jelang waktu magrib.' (Observasi, 17 Februari 2013 pukul 09:45).

Hal yang menarik dari amatan peneliti berhubungan dengan penyesuaian diri bernuansa sosial, ketika menemukan suatu momen yang khas turut melibatkan dua informan peneliti. Dimana pada suatu sore peneliti melihat Informan Budee dan kakak Des duduk bersama salah seorang warga yang kala itu sedang dirundung kesedihan, dikarenakan telah beberapa hari ibu Kandungnya tidak pulang ke rumah. Kedua Informan (Budee dan kakak Des) terlihat sedang menyemangati sembari terus mendengarkan warga tersebut,

'Saat peneliti menuruni setiap blok, dari kejauhan peneliti melihat suasana tampak tidak seperti biasanya. Terlihat wajah-wajah kegelisahan mereka yang duduk di simpang blok $\mathrm{D}$ di bawah pohon Seri. Mendorong peneliti penasaran untuk mengetahui. Ternyata, setelah tiba di pojok rumah blok D (depan rumah pak Ramond) tampak seorang wanita keturunan Tionghua (yang akhirnya peneliti tahu bahwa dia juga tinggal di blok D namun pada lokasi teratas) berparas gelisah, sedih tanpa mengeluarkan air mata dengan terbata-bata berkata, "Ibu sudah tiga hari tidak diketahui keberadaannya. Seringkali lupa rumahnya sendiri di kompleks ini sehingga sewaktu kalau pulang selalu saja diantarkan orang. Ya sudah pikun begitu. Sempat ada informasi dari orang-orang ibu naik Labi-labi (sebutan untuk angkutan umum di Aceh) yaa.. kemana pastinya saya sendiri tidak tahu," ungkap anak tunggal dari korban yang hilang. Kakak Desti yang ada disitu menyemangati dengan penggunanan bahasa Etnisnya (Tionghua) untuk dapat sabar dan mengingatkan ibunya tidak. Sedangkan Budee sesekali menimpali agar sang anak tidak resah dan terus mendoakan ibunya agar bisa segera pulang ke rumah lagi. (Observasi, 16 Februari 2013 pukul 16:30).

Pada kesempatan yang lain, Informan Budee mengakui dirinya menyesuaikan diri di blok D dengan sering bergabung duduk di rumah pak Ramkur dan juga Nenek Laksmi, tetangga berseblahan dengan rumah Informan kakak Des.

“...kalau di sini ya sering saja gabung ke rumah pak Ramond dan nenek Laksmi. Kalau suasana hujan sana tidak berani keluar Budee di rumah saja. Ya ada juga. Kita kan dengan kawan-kawan, misalnya ada orang kawin ya Budee datang aja kalau memang dipanggil. Misalnya Bude tidak datang ya sekedar Budee kasih sedekah aja..." (Wawancara dengan Budee 70 Tahun, rumah blok D-03, 07 Februari 2013 (pukul 10:30 s/d 11:04) 
Terkait dengan informan kakak Des, peneliti sempat mengamati proses penyesuaian informan tersebut di suatu kondisi jelang siang di hari Jumat berlokasi di Puskesmas lingkungan perumahan Jacky Chan,

'Peneliti mendapat kabar bahwa penjadwalan acara pemeriksaan kesehatan di langsungkan hari ini di perumahan Jacky Chan. Sesaat telah berada di Puskesmas yang terletak di blok B. peneliti langsung masuk ke dalam ruangan pemeriksaan. Terlihat di sana dari wajah dan dialek bicara bisa dipastikan yang berkumpul beragam, nada orang Aceh, Jawa, dan China sedang memeriksa balita dan anaknya. Ketika berinisiatif mengambil beberapa gambar berlangsungnya interaksi, peneliti bertemu dengan kak Desti juga membawa anaknya dan mengambil beberapa obat pemesanan tetangga. "Kakak sambil ngecek ni si kecil dan tadi juga pak Ramond minta kakak untuk ambil obat sakit kepala gitu. Katanya dia sih sakit tapi nampaknya memang ia...," Ungkap Kakak Des.' (Observasi, 22 Februari 2013 pukul 10:10)

Mengenai hubungan kakak Des dengan tetangga, disebutkan dalam pernyataannya kerap membantu Nenek Laksmi, yang hidup sendiri dengan usia yang telah renta.

"Ya... saya saling membantu ya. Kadang juga dari klenteng saya ada sumbangan satu sak kepada dia. Saya tidak beda-bedain antara suku jawa, suku batak. Ya ada juga toleransi yang saling membantu jika susah. Ketika kita ada gaji ya beli satu ekor ikan untuk yang kekurangan. Ya setidaknya saat kita bisa berbicara santun apalagi kepada yang lebih tua." (Wawancara dengan kakak Des, 31 tahun, rumah blok D-4106 Februari 2013 pukul 16:30 s/d 16:49).

Selanjutnya, informan Ibu Sisy, yang kedua orang tuanya kelahiran pulau Mentawai. Baginya, perihal menyesuaikan diri menjadi hal terpenting demi menciptakan kebaikan dan kedamaaian mengingat kini informan tinggal di lingkungan yang jauh dari tempat kelahirannya tempat dimana para korban tsunami berkumpul dalam satu pemukiman.

"Gimana kita bilang, Ya namanya kita menyesuaikan diri, kita harus begitu dikit lah dek, ga ada salahnya kita menyebut diri bagian dari orang. Ya Aceh. Karena Ya sekarang dimana kita tinggal ya dimana kita duduk ya disitulah kampong kita. Seakan-akan waktu kita tinggal di sini, Kalau menurut ibu dimanapun tinggal ya sudah menjadi kampong. Kayak ibu sekarang tinggal, kayaknya ibu tinggal tidak sayang dengan orang di sini nanti kalau saya sakit siapa lagi yang bantu kita kalau bukan tetangga. Jadi mau gimana pun kita tinggal harus menyanyangi orang di sini. Walaupun kita bukan asli orang sini. Sekarang asli orang di sini sudah tidak ada (banyak) lagi, sudah bercampur ya korban tsunami pindah ke sini, terus orang yang sudah pergi kita ganti tinggal di sini, 
selama kita masih dikasih kesehatan, kebaikan dan kedamaian ya kita buat kampong ini damai walau kita tidak tahu sejauhmana damainya..." (Wawancara dengan Sisy 46 Tahun, rumah blok F-06, 09 Februari 2013 (pukul 11:00 s/d 12:14).

Tiada berbeda halnya dengan informan ibu Ofa, yang berasal dari keturunan etnis Tionghua yang beragama Kristen. Baginya dikarenakan kesibukkannya di lingkungan perumahan Jacky Chan sebagai penjaga warung yang berseblahan dengan rumahnya di blok B-52. Berkenaan dengan proses penyesuaian diri yang dilakukannya ketika telah ada waktu senggang dari aktivitasnya berdagang. Dalam proses penyesuain diakuinya tidak saja sebatas duduk kumpul bersama, juga terlibat dalam hal mengunjungi

“... kalau saya lagi santai, maka saya gabung duduk bersama. Di sini juga ada kegiatan merangkai bunga untuk saling mengakrabkan kumpul bersama. Kalau misalnya sosialnya ya kalau ada kemalangan (meninggal), ya kita tutup warung dan kita pergi sama-sama untuk berkunjung. Semua warung awalnya tutup, dan tidak ada ada yang ada aturan yang menganjurkan saya untuk tutup warung. Pernah ada orang yang belanja, saya tanyakan, mengapa belanja jauh sampai ke sini. "Memangnya kios di bawah tidak buka? Mereka jawab, "smua warung tutup." Saya ngerasa tidak enak dan akhirnya menutup juga..." (Wawancara dengan ibu Ofa, 63 Tahun, rumah blok B-52, 06 Februari 2013 (pukul 10:10 s/d 11:04)

Selain itu, informan ibu Ofa menuturkan, proses penyesuaian diri juga berlangsung dengan pergi bersama warga lain menjenguk orang yang sakit dan melahirkan.

“... bersama untuk sama-sama pergi ke tempat jenguk orang yang sakit dan ibu yang melahirkan."(Wawancara dengan ibu Ofa, 25 Februari 2013 pada pukul 11: $25 \mathrm{~s} / \mathrm{d}$ 12:03)

Dalam berinteraksi nantinya, Informan ibu Ofa mengaku dirinya yang menetap di blok B sering memperoleh calon pembeli yang berbicara dengan bahasa Aceh. Mensiasati calon pembeli maka ibu Ofa pun berinisiatif bertanya pada tetangga depannya yang juga orang Aceh.

“... di sini (kawasan blok B) ada yang ga bisa bahasa Indonesia sama sekali juga ada,, dalam penggunaan bahasa umum ya pake bahasa Indonesia. Jika ada calon pembeli yang bertanya dengan bahasa Aceh maka saya bertanya kepada orang depan...." (Wawancara dengan Tjueng Siofa 63 Tahun, rumah blok B-52, 06 Februari 2013 (pukul 10:10 s/d 11:04) 
Dalam suatu waktu amatan peneliti mengenai penggunaan bahasa dari Informan ibu Ofa, tampak tiada hal yang menyulitkan Informan meladeni pembeli yang berasal dari suku Aceh.

'... peneliti kembali mendatangi kawasan blok B untuk menemui informan ibu Tjueng Siofa untuk melakukan wawancara tambahan dan mengamati interaksi antara dia dan orang sekitarnya. Sebelum melakukan wawancara peneliti mengamati interaksi antara ibu Ofa pada waktu jelang siang itu sebatas pada hubungan penjual dan pembeli saja. Bisa dihitung sebelum, sedang dan akan meningggalkan rumah informan Tjueng Siofa, ada sekitar 4 pembeli yang datang untuk membeli kebutuhan memasak. Dalam interaksi antara ibu Ofa dan pembelinya, ketika ada yang berujar dengan bahasa Aceh hal itu tidak menjadi kesulitan lagi, "seperti 'nyoe padum saboh? (ini berapa satu), 'peu ka abeh (apa sudah habis) dan beberapa lainnya yang pendek gampang diingat, saya kuasai..." ujar ibu Ofa mempraktikan ucapannya yang masih kaku dengan perkataan bahasa Aceh.' (Observasi 25 Februari 2013 pukul 11:00).

Informan ibu Lusy mengungkapkan perihal bahasa di lingkungannya di blok F, menurutnya berada pada tataran netral saja, terkadang ada yang menggunakan bahasa Indonesia dan di lain waktu menggunakan bahasa Aceh. Akan tetapi pada kenyataan yang sebenarnya lebih dominan pada kaidah penggunaan bahasa Aceh.

“...mengenai bahasa di sini ya netral. Tapi disini lebih mengedepankan bahasa Aceh karena banyaknya orang Aceh di sini..." (Wawancara dengan ibu Lusy, 54 Tahun, rumah blok F-38, 06 Februari 2013 (pukul 14:00 s/d 14:39)

Hal menarik dalam penggunaan bahasa di lingkungan perumahan Jacky Chan dengan apa yang dialami oleh Informan ibu Del,

“... di sini tergantung ya kadang bahasa Aceh, dan kadang juga bahasa Indonesia. Tapi secara umum ya pake bahasa Indonesia. Jika sesame orang Aceh ya mereka sering ngomong bahasa Aceh. Kadang diganti pake bahasa Indonesia kalau ada saya." (Wawancara dengan Siti Deliana, 27 Februari 2013 pukul 17:25 s/d 17:35)

Selain itu, tindakan adaptasi lainnyayang fokus berbicara antara etnis Tionghua (Cina) dengan suku Aceh di perumahan Jacky Chan secara umum dapat disimak melalui pernyataan bapak Ni. Dimana etnis Cina telah mampu bertoleransi bersama seperti terlihat dari kehadiran di sebuah musyawarah yang berlangsung. Serta juga melibatkan dalam kegiatan gotong royong. Bahkan diakui pak Ni, perbedaan antara etnis Cina dan Aceh tampil pada hal beragama dan selebihnya segala praktik atau kegiatan tidak terpisahkan antara keduanya. 
“Toleransi dalam hal musyawarah mereka (etnis Tionghua) sering gabung dengan kami, dalam hal gotong royong... ya gotong royong mereka berbaur dalam kegiatan sosial ya mereka antusias. Yang tampil beda cuma dalam hal beragama saja yang lain dalam kegiatan ya tidak pernah terpisahkan. Jadi tingkat ke gotong-royongan maka respon mereka sangatlah bagus." (Wawancara dengan pak Ni, Sekretaris Perumahan Jacky Chan, 28 Februari 2013 pukul 00:00 s/d 01:54)

Hal yang diungkapkan pak $\mathrm{Ni}$ di atas, berimbang kiranya dengan penuturan dari pak Min,mewakilkan pandangan etnis Cina yang menetap di lingkungan perumahan Jacky Chan,

“... kita hidup sebagai manusia di mana pun sebaiknya jangan sombong, ya... saling tegur sapa. Otomatis dengan waktu singkat akan akrab. Misalnya waktu gotong royong tetap hadir atau misalnya saat maulid ya jika tidak bisa masak ya bantu mengangkat kayu. Yang penting kita mau merendahkan hati dan kita mau membantu sesama." (Wawancara dengan pak Min, ketua Komunitas Etnis Tionghua, rumah blok B-86, 28 Februari 2013 pada pukul 10:49 s/d 11:20).

Ditambahkan pula oleh pak Min, selaku ketua Komunitas etnis Tionghua di perumahan Jacky Chan, menurutnya bahwa proses interaksi dalam penyesuaian diri etnisnya walaupun terkesantidak adanya aturan yang mengawasi segala hal termasuk perihal berinteraksi, tetapi timbul rasa mengatur dari pribadi diri.

"Jika peraturan khusus sih tidak ada, smua rasa pribadi lah. Rasa pribadi kita saling tolong menolong, ya jika tetangga kita tidak saling tolong menolong ya siapa lagi? Bagaimana jauh pun, misalnya kita tetangga di Medan dan kita tinggal di sini maka yang akan duluan membantu ya tetangga di samping rumah. Yang jelas tetangga rumah kita ya sangat akrab. Ketika tadi ada yang lewat ya kita saling menyapa..." (Wawancara dengan pak Min, selaku ketua Komunitas Etnis Tionghua, rumah blok B-86, 28 Februari 2013 pukul 10:50 s/d 11:20). 


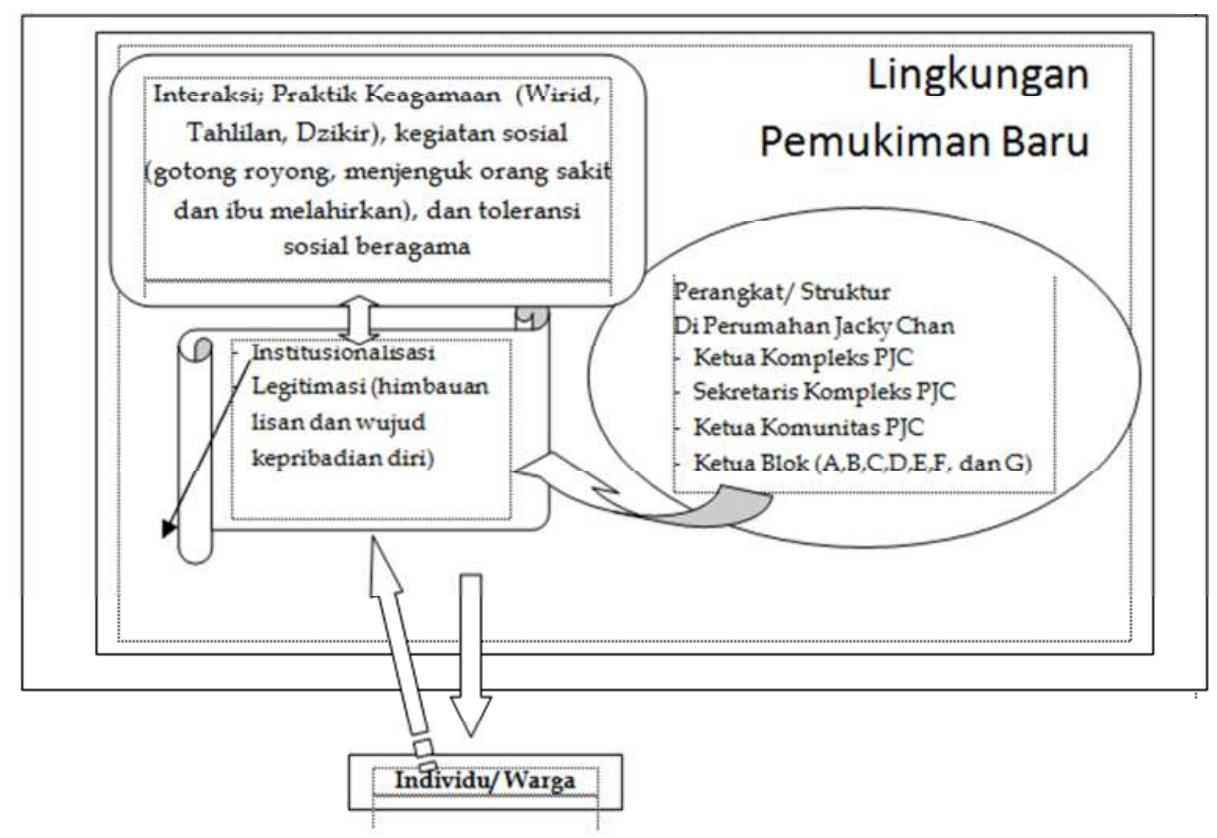

Eskternalisasi pada Kalangan Warga Perumahan Jacky Chan

Dalam interaksi yang berlangsung di kalangan warga perumahan Jacky Chan, yang berlangsung melalui bahasa dan tindakanyang terlihat dari praktik keagamaan dan bernuansa sosial, mendapati serangkaian perilaku;himbauan secara secara lisan, tindakan dan toleransi beragama. Dapat dinyatakan keseluruhannya sesuai dengan apa yang dikatakan dengan tindakan rasional yang berorientasi pada nilai.

\section{KESIMPULAN}

Pada proses penyesuaian diri (Ekternalisasi) di kalangan warga perumahan Jacky Chan terjadi melalui berbagai praktik keagamaannya, seperti Wiridan, Tahlilan, serta kegiatan sosial, yakni bergotong royong, menjenguk orang sakit dan toleransi sosial beragama menjadi lintasan bagi individu untuk melakukan penyesuaian diri (adaptasi) di lingkungan tersebut. Pada proses adaptasi tersebut, sebelumnya akan menghadapkan kalangan warga melewati dua proses terpenting, yaitu Institusional (kelembagaan) dan Legitimasi.Apa yang kiranya diupayakan pada Institusional merupakan bahagian dari keinginan menghadirkan keteraturan (perkumpulan) dengan turut hadirnya pembagian peranan sehingga terbentuknya acara Wiridan, Tahlilan. Dan pada proses legitimasi pada kalangan warga di perumahan Jacky Chan memiliki legitimasi sebatas pada legitimasi informal, yakni berupa himbauan (bahasa 
Community; Volume 2, Nomor 3, Oktober 2016

ISSN: 2477-5746

verbal dalam rapat atau pertemuan tidak terencana) dan rasa kepribadian (peka) mengawasi interaksi yang berjalan di lingkungan perumahan tersebut. Dari kedua proses tersebut, bahasa dan tindakan menjadi penggerak bagi individu di kalangan warga perumahan tersebut melakukan adaptasi dirinya.

\section{DAFTAR PUSTAKA}

Alo Liliweri. 2010.Strategi Komunikasi Masyarakat. Yogyakarta: LkiS

David C. Korten \& Sjahrir (ed). 1988.Pembangunan Berdimensi Kerakyatan, (Jakarta: Yayasan Obor Indonesia

E Kristi Poerwandari. 1994.Pendekatan Kualitatif dalam penelitian Psikologi. Jakarta: LPSP3

Jalaluddin Rakhmat. 1985.Metode Penelitian Komunikasi. Bandung, Remaja Rosdakarya

Nina W. Syam. 2009.Sosiologi Komunikasi. Bandung: Humaniora

S. Nasution. 2006. Metode Research: Penelitian Ilmiah. Jakarta: Bumi Aksara

Sugiyono. 2007. Memahami Penelitian Kualitatif. Bandung: Alfabeta

\section{Website}

AcehTourismAgencyOnline, Kampung Jacky Chan di Aceh, diposting pada tanggal 19/11/2012, pada pukul 18:09, pada situs, http:/ / acehtourismagency.blogspot.com/2012/08/kampung-jacky-chan 